\title{
Incidence of urinary retention and relations between patient's complaint, physical examination, and bladder ultrasound
}

\author{
Incidência de retenção urinária e relações entre queixa do \\ paciente, exame físico e ultrassonografia vesical \\ Incidencia de la retención urinaria y relaciones entre queja del \\ paciente, examen físico y ultrasonografía vesical
}

\author{
Rodrigo do Nascimento Cerattia \\ Mariur Gomes Beghetto ${ }^{b}$
}

\section{How to cite this article:}

Ceratti RN, Beghetto MG. Incidence of urinary retention and relationships between patient's complaint, physical examination, and bladder ultrasound. Rev Gaúcha Enferm. 2021;42:e20200014. doi: https://doi.org/10.1590/19831447.2021.20200014
Hospital de Clínicas de Porto Alegre (HCPA). Porto Alegre, Rio Grande do Sul, Brasil.

Universidade Federal do Rio Grande do Sul (UFRGS), Escola de Enfermagem, Departamento de Assistência e Orientação Profissional. Porto Alegre, Rio Grande do Sul, Brasil.

\section{ABSTRACT}

Objective: To describe the frequency of urinary complaints, bladder globe, and need for bladder relief catheterization according to ultrasound; to investigate the relationship between the urinary volume estimated by ultrasound and the one drained in catheterization; and to describe the relationship of patient's complaints and detection of bladder globe with the diagnosis of urinary retention.

Method: A cross-sectional study with clinical patients with suspected urinary retention in a tertiary hospital, conducted from February to September 2018. Urinary volume $\geq 500 \mathrm{~mL}$ in ultrasound was considered urinary retention.

Results: Two hundred and five evaluations were performed in 44 patients. Urinary retention was detected by ultrasound in 33.2\% of the evaluations. There was a strong correlation between ultrasound and bladder catheterization. There was a higher frequency of identification of bladder globe in urinary volumes $\geq 300 \mathrm{~mL}$.

Conclusion: The incidence of urinary retention was higher when ultrasound was used for the diagnosis, when compared to patient's complaint and physical examination. Ultrasound showed to be accurate in establishing urinary volume.

Keywords: Urinary retention. Ultrasonography. Nursing. Patient safety.

\section{RESUMO}

Objetivo: Descrever frequência de queixas urinárias, globo vesical e necessidade de cateterismo vesical de alívio a partir da realização da ultrassonografia; verificar relação entre volume urinário estimado pela ultrassonografia e drenado no cateterismo e descrever relação entre queixas dos pacientes e detecção de globo vesical com o diagnóstico de retenção urinária.

Método: Estudo transversal com pacientes clínicos com suspeita de retenção urinária, no período de fevereiro a setembro de 2018, em um hospital terciário. Volume urinário $\geq 500 \mathrm{~mL}$ na ultrassonografia foi considerado retenção urinária.

Resultados: Realizaram-se 205 avaliações, em 44 pacientes. Detectou-se retenção urinária pela ultrassonografia em 33,2\% das avaliações. Houve forte correlação entre ultrassonografia e cateterismo vesical. Verificou-se maior frequência de identificação de globo vesical em volumes urinários $\geq 300 \mathrm{~mL}$.

Conclusão: Incidência de retenção urinária foi maior quando a ultrassonografia foi empregada para o diagnóstico, quando comparado à queixa do paciente e exame físico. Ultrassonografia mostrou-se precisa em determinar volume urinário.

Palavras-chave: Retenção urinária. Ultrassonografia. Enfermagem. Segurança do paciente.

\section{RESUMEN}

Objetivo: Describir la frecuencia de las quejas urinarias, el globo vesical y la necesidad del cateterismo de la vejiga por ultrasonido; verificar la relación entre el volumen urinario estimado por ultrasonido y drenado en el cateterismo y describir la relación entre las quejas de los pacientes y la detección de globo vesical y el diagnóstico de retención urinaria.

Método: Estudio transversal con pacientes clínicos con sospecha de retención urinaria, realizado entre febrero y septiembre de 2018 en un hospital de nivel terciario. El volumen urinario $\geq 500 \mathrm{~mL}$ en el ultrasonido se consideró retención urinaria.

Resultados: Se realizaron 205 evaluaciones en 44 pacientes. La retención urinaria se detectó por ultrasonido en el 33,2\% de las evaluaciones. Hubo una fuerte correlación entre el ultrasonido y el cateterismo vesical. Se registró una mayor frecuencia de identificación de globo vesical en volúmenes urinarios superiores a $300 \mathrm{~mL}$.

Conclusión: La incidencia de la RU fue mayor cuando se empleó ultrasonografía para el diagnóstico, comparado con la queja del paciente y el examen físico. La ultrasonografía se mostró precisa en determinar el volumen urinario.

Palabras-claves: Retención urinaria. Ultrasonografía. Enfermería. Seguridad del paciente. 


\section{INTRODUCTION}

On average, an adult produces nearly 1,200 $\mathrm{mL}$ of urine daily. The usual capacity of the bladder is from $300 \mathrm{~mL}$ to $500 \mathrm{~mL}$ but, when it reaches from $200 \mathrm{~mL}$ to $300 \mathrm{~mL}$, the neuroceptors responsible for the urination reflex are stimulated, triggering the need to urinate ${ }^{(1)}$. For different reasons, some patients experience total or partial impairment of bladder emptying, a condition called urinary retention $(\mathrm{UR})^{(1-2)}$.

There is no consensus in the literature regarding the urinary volume that characterizes $U R^{(3-4)}$. Some authors suggest values from $300 \mathrm{~mL}$ to $500 \mathrm{~mL}^{(5-6)}$, whereas another study defined UR as a persistent post-void residual of more than $300 \mathrm{~mL}^{(4)}$.

The lack of clear criteria to determine UR contributes to the great variability in the description of the incidence rates for this event. The literature on the theme is almost exclusively limited to studies with surgical patients, mainly in the immediate post-anesthesia period. In this context, the incidence of UR ranges from $2 \%$ to $60 \%$ and is especially related to the type of surgery performed, the type of anesthesia administered, and the use of anticholinergic or analgesic drugs ${ }^{(7-9)}$.

Different diagnostic tests are used to identify UR. The first is assessing patient's complaints. Sensation of full bladder, suprapubic pain, and inability to empty the bladder can be indicative of $U R^{(10)}$. Complementary to the patient's complaint, the physical examination of the bladder has an important role in detecting UR. However, both palpation and percussion showed great limitations. A study points out that the use of clinical signs and symptoms alone can impair the diagnosis of UR, since they are subjective and dependent on the examiner's experience, which can lead to under- or over-estimation of urinary volumes at the time of bladder catheterization ${ }^{(11)}$.

More recently, the identification of urinary volume by ultrasound (US) has been tested, showing to be a useful diagnostic method for the detection of UR at the bedside ${ }^{(12)}$. Furthermore, a research study found a strong correlation between the urinary volume estimated by US and the one drained from urinary catheterization ${ }^{(11)}$. Another study, conducted in a post-anesthetic recovery room (PARR), corroborates this finding, showing a relationship between the urinary volume estimated by US and the one drained from bladder catheterization ${ }^{(14)}$.
Although the use of US at the bedside has shown to be a useful tool in estimating urinary volume to avoid unnecessary catheterization ${ }^{(13,15)}$, in most health care facilities, the detection of UR is exclusively based on patients' complaints and on clinical assessment, which can compromise patient safety, exposing them to unnecessary invasive procedures ${ }^{(15)}$. In this context, the diagnosis of UR is retrospective, only being determined after urinary catheterization.

Although studies on the subject are limited to the postoperative setting, they demonstrate that the use of US at the bedside by nurses represents a rapid, non-invasive and reliable way to detect $U R^{(7)}$. Additionally, a specific legislation establishes standards for this practice by nurses, as long as they are duly qualified ${ }^{(16)}$.

However, in the Brazilian setting, few health care facilities for clinical patients have equipment and nurses qualified in the use of this technology. Even in health care facilities where these resources are available, the Nursing practice is still based on an empirical model of clinical decision-making, compromising clinical reasoning, decision-making, and the efficacy of the nurses' work $^{(12)}$.

Given the scarce literature about signs and symptoms of UR in clinical patients and the diversity of care practices for the diagnosis of UR, the present study aims to: (1) describe how frequently patients present urinary complaints, nurses identify the presence of bladder globe and determine the need of bladder relief catheterization (BRC) based on US; (2) investigate the relationship between the urinary volume estimated by US and the one drained in BRC; and (3) describe the relationship of patient's complaints and detection of bladder globe with diagnosis of $U R$, defined by two different criteria (urine volumes: $300 \mathrm{~mL}$ to $499 \mathrm{~mL}$ and $\geq 500 \mathrm{~mL}$ ).

\section{METHOD}

In 2018, a cross-sectional quantitative study was conducted in a clinical unit of a tertiary public university hospital in southern Brazil that admits older adults (age $>60$ years old) and adults on palliative care. The study included patients assessed for suspected UR, except for those who concomitantly made use of a cystostomy, urostomy or nephrostomy catheter or for those who had any anatomical alteration that made it impossible to perform US or BRC according to the standard procedure (patients who required guided bladder catheterization or whose procedure should be performed by the Urology team). 
The researchers developed a research instrument and a guide for its completion. Data collection was administered by the nurses $(n=9)$ working in all shifts who performed US scans as part of their routine care practice. All the participating nurses had already been duly qualified by theoretical-practical training since 2014 and were considered qualified by experts in US. The training of the Nursing team and the implementation of this routine resulted from the fact that many patients have undergone unnecessary urinary catheterization.

Prior to data collection, agreement between raters yielded a Kappa of 0.783 (95\% Cl: 0.703 - 0.996) (data not shown), and all the nurses were trained with regard to the research procedures and instrument; the same protocol was employed by all the nurses, in the evaluation of all the patients. The same patient may have been assessed by different nurses at different times, but no patient was assessed more than once by the same nurse. A form was used for each evaluation, even in cases of more than one evaluation for the same patient, meaning that the nurses were blinded for the other evaluations.

Sample size was calculated using two software programs (Epi Info v.7 and Winpepi), considering a 5\% error and a sample power greater than $90 \%$, for an expected incidence of $30 \%$. Patients were included in the sample by means of non-probability consecutive sampling from February to September 2018,

as they presented any suspicion of UR, such as long time without urinating (longer than 6 hours), suprapubic pain, and inability to empty bladder. This "triggered" the conduction of evaluations.

All the evaluations followed the same routine, respecting the same order of procedures: (1) the "patient's complaints" related to UR were heard, and the patients were asked about their perception on the need to urinate. If a patient was unable to report his/her complaints regarding the impression of UR and on the need to urinate, due to some neurological disorder or to any other reason, questions were directed to his/her companion. In this case, the companion was asked about how long the patient had gone without urinating or if he/she noticed some discomfort that could suggest difficulty urinating; (2) the nurse performed a clinical examination (palpation of the suprapubic region seeking for bladder globe and other signs of UR) and issued opinions for the following questions: "Does the patient present signs of UR?" and "Does the patient require BRC?"; (3) US was performed

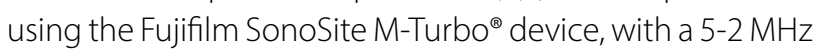
curvilinear transducer. For all the cases, US was performed according to the established standards documented by the study institution. The estimated value of bladder content was calculated and provided by the equipment. Based on the data obtained from US, the nurse recorded the estimated urinary volume on the research form and issued an opinion for the following question: "Based on the volume obtained from US, would you perform BRC?"

After each evaluation, the nurse decided whether to perform bladder catheterization or not. All bladder catheterizations were performed according to the standards of the study institution, using 10, 12 or 14 French urethral catheters. The urinary volume obtained was measured using a transparent measuring jar, graded in milliliters, with graduation marks every $10 \mathrm{~mL}$.

Considering that bladder volume usually ranges from $300 \mathrm{~mL}$ to $500 \mathrm{~mL}^{(1)}$, and following a parameter previously adopted in another research study ${ }^{(15)}$, for the purposes of the present study, urinary volumes $\geq 500 \mathrm{~mL}$ (estimated by US and drained in bladder catheterization) were considered "Urinary Retention (UR)". Additionally, the authors consider that volumes from $300 \mathrm{~mL}$ to $499 \mathrm{~mL}$ also characterize $U R^{(5-6)}$. Therefore, the analysis of incidences took these criteria into account.

Data were typed and analyzed using the Statistical Package for the Social Sciences (SPSS) software, version 24.0. Initially, the Shapiro-Wilk test was applied to determine normality in the distribution of continuous variables. Subsequently, a descriptive analysis was performed, with results expressed as mean $\pm S D$, median (P25 - P75), or absolute and relative frequencies, according to the characteristics and distribution of the variables. Proportions were compared using the chisquare test, and Yates correction or the Fisher's exact test were applied when indicated. The correlation between the estimated volume obtained by US and the urine volume drained in bladder catheterization was assessed using the Spearman's correlation test and a Bland-Altman Plot. p-values $<0.05$ were considered statistically significant. For the purposes of this analysis, the urine volumes identified by US were considered as the reference standard.

The study complied with the Guidelines and Regulatory Standards for Research Involving Human Subjects (CNS Resolution No.466, of December $12^{\text {th }}, 2012$ ) and complementary to the National Health Council; in addition; it was approved by the Research Ethics Committee of the study institution with regard to its ethical and methodological aspects (CAE: 73406017.4.0000.5327). The patients participating in the study gave their consent through a specific FICF. 


\section{RESULTS}

Of the patients admitted to the unit and eligible for the study, only 44 presented some of the conditions considered as "triggers" for suspected UR and were actually included. The mean age of the patients was $67.7 \pm 12.9$ years old. In addition, they were predominantly women (56.8\%), were admitted for urinary tract infection (UTI) (22.7\%), and had one or more chronic diseases, of which neoplasm was the most prevalent (68.2\%), followed by arterial hypertension (56.0\%) and diabetes mellitus (30.0\%).

Each patient included in the study was assessed at least once. None of the patients was assessed more than once by the same nurse. The number of times each patient was assessed by one of the nurses is summarized in Table 1, totaling 205 evaluations, with the results reported below.

Complaints suggestive of UR occurred in $30.2 \%$ of the 205 evaluations. The most frequent complaints were long time without urinating (56.6\%), followed by inability to completely empty the bladder (35.1\%), and sensation of full bladder and, thus, these patients should undergo bladder relief catheterization (20.5\%). In 21.0\% of evaluations, the nurses detected the presence of bladder globe. Based on the US results, the nurses indicated the conduction of BRC in $33.2 \%$ of the 205 evaluations. These data are summarized in Table 2.

Only 68 evaluations resulted in the indication of BRC. Of these, $61.2 \%$ occurred due to urinary complaints, $48.5 \%$ due to the presence of bladder globe, and in all the cases in which US suggested the nurses to indicate BRC (based on the volumes found in US).

There was a strong correlation $(r=0.997 ; p<0.005)$ between the urinary volume estimated by US $(493.1 \pm 185.4 \mathrm{~mL})$ and the urinary volume drained when BRC was
Table 1 - Number of evaluations made to each of the 44 patients included in the study, with data expressed as absolute numbers and proportion in parenthesis. Brazil, 2018

\begin{tabular}{lcc}
$\begin{array}{l}\text { Number of } \\
\text { evaluations }\end{array}$ & $\mathbf{n ( \% )}$ & Frequency \\
\hline 1 & $1(2.2)$ & 1 \\
2 & $3(6.9)$ & 6 \\
3 & $7(16.0)$ & 21 \\
4 & $13(29.5)$ & 52 \\
5 & $8(18.2)$ & 40 \\
6 & $6(13.6)$ & 36 \\
7 & $2(4.5)$ & 14 \\
8 & $1(2.2)$ & 8 \\
9 & $3(6.9)$ & 27 \\
Total & $\mathbf{4 4 ( 1 0 0 )}$ & $\mathbf{2 0 5}$ \\
\hline
\end{tabular}

Source: Research data, 2018.

performed ( $501.9 \pm 184.7 \mathrm{~mL}$ ). The mean difference between the volume obtained in BRC and the volume estimated by US was $9.02 \mathrm{~mL} \pm 13.99 \mathrm{~mL}$. Corroborating with these findings, the Bland-Altman Plot shows the detailed comparison between the two variables (Graphs 1 and 2). The urinary volume estimated by US was used to identify the incidence of UR (urinary volume $\geq 500 \mathrm{~mL}$ ), according to each diagnostic method.

When comparing the frequency of patients' complaints and detection of bladder globe according to the different

Table 2 - Complaints suggestive of urinary retention, detection of bladder globe, and US findings $(n=205)$. Brazil, 2018

\section{Evaluation criteria}

Dysuria

Inability to empty the bladder

Long time without urinating

Bladder pain or discomfort

Sensation of full bladder

Nurse's perception on the presence of bladder globe

Decision to perform BRC based on US

\section{(\%)}

0.5

35.1

56.6

12.7

20.5

21.0

33.2

Source: Research data, 2018. 
ranges of urinary volume for the diagnosis of UR described in the literature $(<300 \mathrm{~mL}, 300 \mathrm{~mL}$ to $399 \mathrm{~mL}$, and $>500 \mathrm{~mL})$, it was verified that the presence of bladder globe was more frequent when the urinary volumes estimated by US were higher than $300 \mathrm{~mL}(p<0.001)$. None of the urinary complaints reported by the patients was more frequent in any of the three ranges of urinary volume ( $p>0.005$ for all the comparisons). However, it is worth noting that the proportion of sensation of full bladder was more frequent (33.3\% vs 19.6\% vs 18.5\%) in the category with the highest urinary volume $(\geq 500 \mathrm{~mL})$. The results are shown in Table 3.

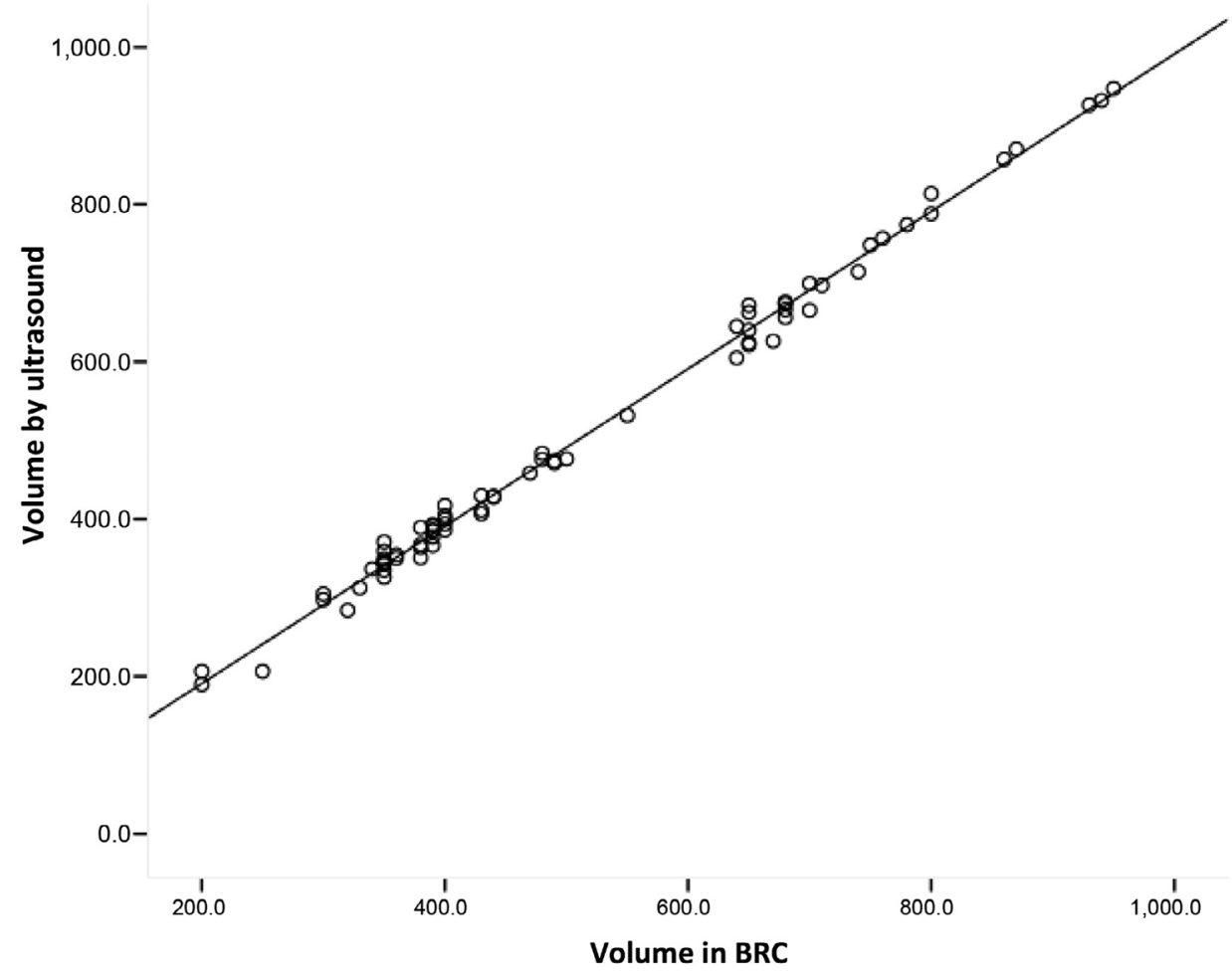

Graph 1 - Correlation between the volume estimated by US (in $\mathrm{mL}$ ) and the volume drained in bladder relief catheterization (in $\mathrm{mL})(\mathrm{n}=68)(\mathrm{r}=0.997 ; \mathrm{p}<0.001)$. Brazil, 2018

Source: Research data, 2018.

Table 3 - Comparison of the variables for the diagnosis of UR in the different volume categories that define the condition ( $\mathrm{n}=205)$. Brazil, 2018

\begin{tabular}{lcccc} 
Variable & $\begin{array}{c}<\mathbf{3 0 0} \mathbf{~} \mathbf{L} \\
\mathrm{n}=135(65.9)\end{array}$ & $\begin{array}{c}\mathbf{3 0 0} \mathbf{~ \mathbf { L }}-\mathbf{4 9 9} \mathbf{~ \mathbf { L }} \\
\mathrm{n}=46(22.4)\end{array}$ & $\begin{array}{c}\geq \mathbf{5 0 0} \mathbf{~} \mathbf{L} \\
\mathrm{n}=24(11.7)\end{array}$ & $\mathbf{p}$ \\
Dysuria & $1(0.7)$ & 0 & 0 & 0.650 \\
Inability to empty the bladder & $48(35.6)$ & $14(30.4)$ & $10(41.7)$ & 0.636 \\
Long time without urinating & $74(54.8)$ & $26(56.5)$ & $16(66.7)$ & 0.558 \\
Bladder pain/discomfort & $17(12.6)$ & $7(15.2)$ & $2(8.3)$ & 0.713 \\
Sensation of full bladder & $25(18.5)$ & $9(19.6)$ & $8(33.3)$ & 0.250 \\
$\begin{array}{l}\text { Presence of bladder globe } \\
\text { (nurse's assessment) }\end{array}$ & $12(8.9)$ & $16(34.8)$ & $15(62.5)$ & 0.000 \\
\hline
\end{tabular}

Source: Research data, 2018. 


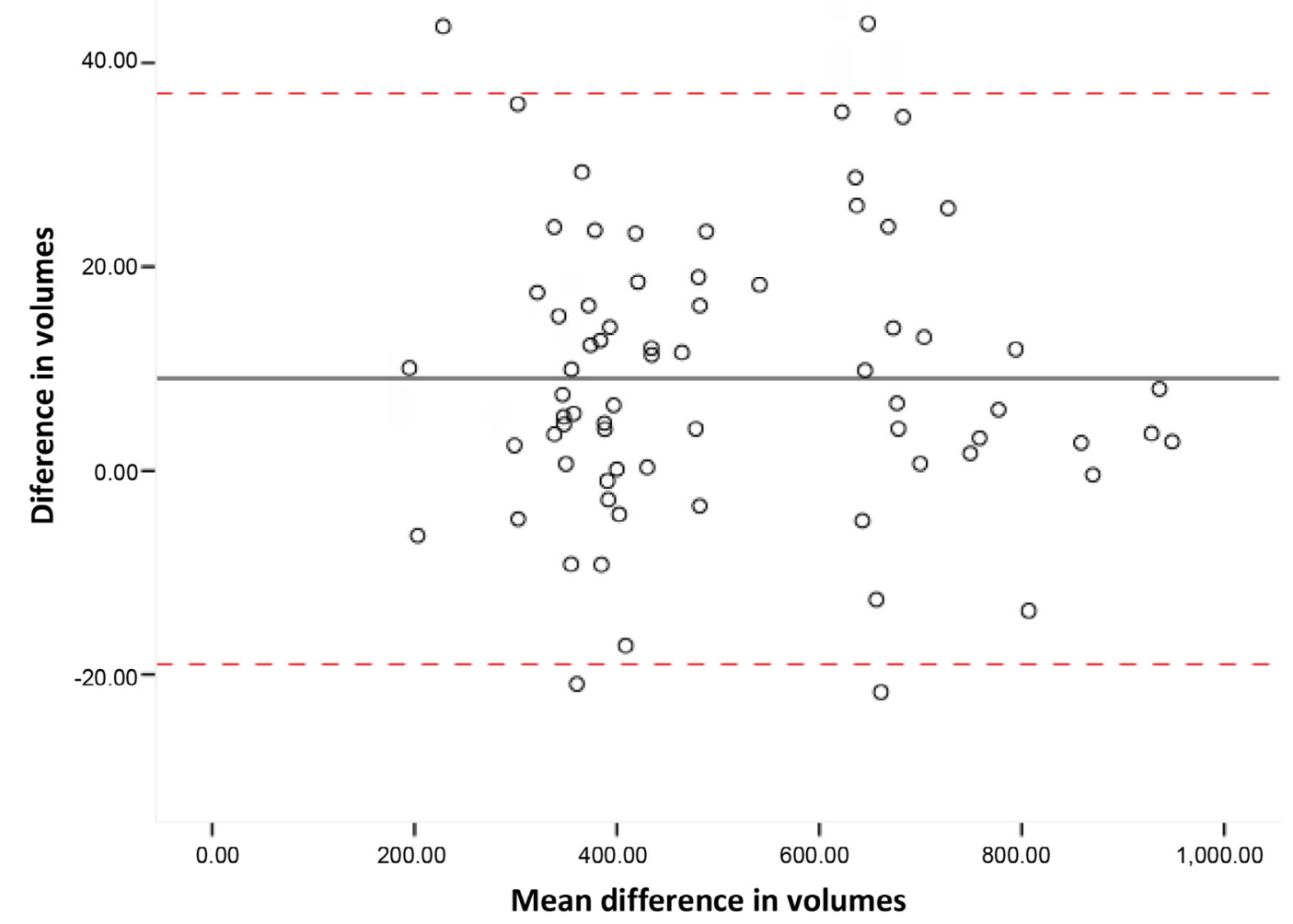

Graph 2 - Relationship between the mean of the difference and the mean difference between the values estimated by performing US at the bedside and the volumes drained in bladder relief catheterization (Bland-Altman Plot). The solid line represents the mean values, whereas the dashed lines represent \pm 2 standard deviations. Data expressed in $\mathrm{mL}(n=68)$. Brazil, 2018

Source: Research data, 2018.

\section{DISCUSSION}

The results of the present study show variability in the incidence of the different complaints suggestive of UR, of which "long time without urinating" was the most frequent (56.6\%), and reveal that bladder globe was an incident found in nearly $1 / 5$ of the evaluations. There was a strong correlation between the urinary volume estimated by US and the one drained in BRC, allowing for the urine values estimated by US to begin to be used as reference for the comparisons. Patients' complaints were not shown to be associated with higher urinary volumes, but the presence of bladder globe was.

Although US has shown to be a useful diagnostic resource to identify urinary volume, a better understanding on UR lacks the establishment of parameters (urinary values) that clearly define $U R$, which is not still a consensus in the literature ${ }^{(4,17)}$. Nevertheless, it is perceived that methods employed for the identification of UR that involve greater subjectivity may disagree among each other, in the absence of objective parameters, not contributing with nurses in deciding on whether to perform BRC or not ${ }^{(12)}$.

This lack of criteria to diagnose UR and, therefore, to indicate $B R C$, contributes to the great variability in the incidence rates of UR described in the literature. Several studies ${ }^{(7-9,18-20)}$ report incidence rates ranging from $2 \%$ to $60 \%$, which is consistent with those we found when assessing incidence in the categories suggested in the literature $(<300 \mathrm{~mL}$, from $300 \mathrm{~mL}$ to $499 \mathrm{~mL}$, and $\geq 500 \mathrm{~mL}$ ). However, the incidence rates found in the literature come from studies predominantly conducted with patients in the immediate postoperative period or admitted to post-surgical units.

In a study that prospectively assessed 174 patients in the postoperative period of hip arthroplasty, 43.7\% developed UR and required BRC. According to the authors, UR was monitored based on the patient's complaints of suprapubic 
discomfort or inability to urinate. Considering results for bladder US, patients with urinary volume higher than $400 \mathrm{~mL}$ were characterized as having UR and thus underwent BRC. There was no comparison between the volumes obtained from US and in BRC ${ }^{(20)}$.

The complaints of the patients, either clinical or surgical, are extremely important for subsequent evaluations, in order to achieve early identification of UR. In a complementary manner, US can help professionals decide on whether to perform BRC or not, according to the urinary volume defined as a characteristic feature of UR.

The use of US has been shown to be useful in detecting urinary volumes very close to those obtained from BRC. Patients with a urinary volume of more than $400 \mathrm{~mL}$ had a mean difference of $21.8 \mathrm{~mL} \pm 59.9 \mathrm{~mL}$ between the volume identified by US and that drained in BRC in a cohort of 105 surgical patients ${ }^{(21)}$.

A strong correlation between the urinary volumes identified by US and those obtained in BRC are documented in other research studies ${ }^{(13-14)}$. They show that urine values estimated by US can be used as a reference standard to characterize $U R$, in terms of urinary volume, as long as there is a cutoff point for decision-making about catheterization. This would be very useful in the care practice, because it would minimize cases of unnecessary BRC, i.e., in the absence of UR, thus preventing patient discomfort, urethral trauma, and urinary infection, and also reducing related costs ${ }^{(19)}$. The opposite is also true. According to a diagnostic standard, bladder US can indicate the need for bladder emptying (BRC), thus preventing bladder distension and other discomforts.

Nurses have a key role in determining UR, but diagnostic assertiveness involves many aspects, such as the examiner's experience, and the ability in performing physical examination, in addition to the use of additional resources, such as US. The use of this technology allows nurses to establish a more assertive diagnosis of UR, reducing the subjective nature of their evaluation, which can lead to misdiagnosis, and attaining safer care for the patient ${ }^{(22)}$.

\section{CONCLUSION}

The most frequent urinary complaint was long time without urinating $(56.6 \%)$, followed by inability to empty the bladder (35.1\%). The nurses identified UR in $21 \%$ of the evaluations. The incidence of UR was higher when US was used in the diagnosis. The US exam at the bedside, conducted by nurses, has shown to be accurate in estimating the urinary volume in comparison to the volume obtained from BRC.
In addition to that, higher urinary volumes estimated by US ( $\geq 500 \mathrm{~mL}$ ) have a greater relationship with the identification of UR by nurses based on palpation of bladder globe.

It is worth noting that the present study has limitations. Although the number of observations conducted is equal to or greater than that of other studies herein presented, it should be considered that the sample power was insufficient to proceed with stratified analyses and to assess the diagnostic properties and accuracy of the methods to estimate UR (sensation of full bladder, nurse's clinical judgment, and judgment after US).

Finally, it is emphasized that this study assessed the similarities and differences between the methods to identify UR at the bedside in clinical patients, unlike most previous studies, which aimed to analyze surgical patients. Moreover, the present study opens a door to determine, in the future, which urinary volume would establish the condition of UR in clinical patients, in addition to protocols to help nurses make a more accurate diagnosis, promoting safer and more qualified care.

\section{REFERENCES}

1. Mindardi D. Urinary retention. Bristol: ICS Committees, 2018 [cited 2019 Nov 22]. Available from: https://www.ics.org/committees/standardisation/ terminologydiscussions/urinaryretention

2. Royal College of Nursing, Australia. Adult urinary obstruction, retention and bladder scanning: a self directed resource package. Sydney; 2011.

3. Negro CL, Muir GH. Chronic urinary retention in men: how we define it, and how does it affect treatment outcome. BJU Int. 2012 Dec;110(11):1590-4. doi: https://doi.org/10.1111/j.1464-410X.2012.11101.x

4. Stoffel JT, Peterson AC, Sandhu JS, Suskind AM, Wei JT, Lightner DJ. AUA White paper on nonneurogenic chronic urinary retention: consensus definition, treatment algorithm, and outcome end points. J Urol. 2017 July;198(1):153-60. doi: https://doi.org/10.1016/j.juro.2017.01.075

5. Wareing M. Urinary retention: issues of management and care. Emerg Nurse. 2013 Dec;11(8):24-7. doi: https://doi.org/10.7748/en2003.12.11.8.24.c1139

6. Bala KG, Chou Y. Ultrasonography of the urinary bladder. J Med Ultrasound. 2010;18(3):105-14. doi: https://doi.org/10.1016/S0929-6441(10)60015-X

7. Mago AJD, Helayel PE, Bianchini E, Kozuki H, Oliveira Filho GR. Prevalência e fatores preditivos de retenção urinária diagnosticada por ultrassonografia no período pós-anestésico imediato. Rev Bras Anestesiol. 2010;60(4):387-90. doi: https://doi.org/10.1590/S0034-70942010000400005

8. Bjerregaard LS, Bogo S, Raaschou S, Troldborg C, Hornum U, Poulsen AM, et al. Incidence of and risk factors for postoperative urinary retention in fast-track hip and knee arthroplasty: a prospective, observational study. Acta Orthop. 2015 Apr;86(2):183-8. doi: https://doi.org/10.3109/17453674.2014.972262

9. Niazi AAA, Taha MAA. Postoperative urinary retention after general and spinal anesthesia in orthopedic surgical patients. Egypt J Anaesth. 2015;31(1):65-9. doi: https://doi.org/10.1016/j.egja.2014.12.002 
10. Keita H, Diouf E, Tubach F, Brouwer T, Dahmani S, Mantz J, et al. Predictive factors of early postoperative urinary retention in the postanesthesia care unit. Anesth Analg. 2005 Aug;101(2):592-6. doi: https://doi.org/10.1213/01. ane.0000159165.90094.40

11. Lamonerie L, Marret E, Deleuze A, Lembert N, Dupont M, Bonnet F. Prevalence of postoperative bladder distension and urinary retention detected by ultrasound measurement. Br J Anaesth. 2004 Apr;92(4):544-6. doi: https://doi. org/10.1093/bja/aeh099

12. Carnaval, BM, Teixeira, AM, Carvalho, R. Use of portable ultrasound to detect urinary retention by nurses in anesthesia recovery. Rev SOBECC. 2019;24(2):918. doi: https://doi.org/10.5327/21414-4425201900020007

13. Meska MHG, Mazzo A, Jorge BM, Souza-Junior VD, Negri EC, Chayamiti EMPC. Urinary retention: implications of low-fidelity simulation training on the selfconfidence of nurses. Rev Esc Enferm USP. 2016;50(5):833-9. doi: https://doi. org/10.1590/s0080-623420160000600017

14. Ozturk NK, Kavakli AS. Use of bladder volume measurement assessed with ultrasound to predict postoperative urinary retention. North Clin Istanb. 2017 Jan;3(3):209-16. doi: https://doi.org/10.14744/nci.2016.03164

15. Lee YY, Tsay WL, Lou MF, Dai YT. The effectiveness of implementing a bladder ultrasound programme in neurosurgical units. J Adv Nurs. 2007 Jan;57(2):192200. doi: https://doi.org/10.1111/j.1365-2648.2006.04080.x

16. Conselho Regional de Enfermagem São Paulo (BR). Parecer COREN-SP 029/2014 - CT. PRCI no 1530/2014. Uso do ultrassom pelo enfermeiro para cálculo de volume em retenção urinária. São Paulo; 2014 [cited 2020 Jan 10]. Available from: https://portal.coren-sp.gov.br/wp-content/uploads/2014/08/ parecer_coren_sp_2014_029.pdf
17. Justo D, Schwartz N, Dvorkin E, Gringauz I, Groutz A. Asymptomatic urinary retention in elderly women upon admission to the Internal Medicine department: a prospective study. Neurourol Urodyn. 2017 Mar;36(3):794-7. doi: https://doi.org/10.1002/nau.23029

18. Daurat A, Choquet O, Bringuier S, Charbit J, Egan M, Capdevila X. Diagnosis of postoperative urinary retention using a simplified ultrasound bladder measurement. Anesth Analg. 2015 May;120(5):1033-8. doi: https://doi. org/10.1213/ANE.00000000000000595

19. Thanagumtorn K. Accuracy of post-void residual urine volume measurement using an ultrasound bladder scanner among postoperative radical hysterectomy patients. J Med Assoc Thai. 2016 Oct [cited 2020 Jan 10];99(10):10616. Available from: http://www.jmatonline.com/index.php/jmat/article/ view/7658

20. Lawrie CM, Ong AC, Hernandez VH, Rosas S, Post ZD, Orozco FR. Incidence and risk factors for postoperative urinary retention in total hip arthroplasty performed under spinal anesthesia. J Arthroplasty. 2017 Dec;32(12):3748-51. doi: https://doi.org/10.1016/j.arth.2017.07.009

21. Brouwer TA, Van den Boogaard C, Van Roon EN, Kalkman CJ, Veeger N. Noninvasive bladder volume measurement for the prevention of postoperative urinary retention: validation of two ultrasound devices in a clinical setting. J Clin Monit Comput. 2018 Dec;32(6):1117-26. doi: https://doi.org/10.1007/ s10877-018-0123-6

22. Jorge, BM, Mazzo, A, Napoleão, AA, Bianchini, A. Scientific evidence of urinary retention diagnostic practices: scoping review. Rev Enferm UERJ. 2018 Set;26:e25840. doi: https://doi.org/10.12957/reuerj.2018.25840

\section{- Corresponding author:}

Rodrigo do Nascimento Ceratti

Email: rcertti@hcpa.edu.br

\section{Associate editor:}

